Pobrane z czasopisma Studia Iuridica Lublinensia http://studiaiuridica.umes.pl Data: 26/04/2023 12:37:52

Articles Studia luridica Lublinensia vol. XXX, 2, 2021 DOI: $10.17951 /$ sil.2021.30.2.33-47

Tomasz Brzezicki

Nicolaus Copernicus University in Toruń, Poland ORCID: 0000-0003-1048-1402 brzoza@umk.pl

Piotr Rączka

Nicolaus Copernicus University in Toruń, Poland ORCID: 0000-0002-1097-5712 raczka@umk.pl

Jacek Wantoch-Rekowski

Nicolaus Copernicus University in Torun, Poland ORCID: 0000-0002-1606-7790

rekowski@umk.pl

\title{
Legal Aspects of the Imposition and Enforcement of an Administrative Penalty for Failure to Register a Vehicle Imported from the Territory of a European Union Member State
}

Prawne aspekty wymiaru i egzekucji kary administracyjnej z tytułu niezarejestrowania pojazdu sprowadzonego z terytorium państwa członkowskiego Unii Europejskiej

CORRESPONDENCE ADDRESS: Tomasz Brzezicki, PhD, dr. habil., Associate Professor; Piotr Rączka, PhD, dr. habil., Associate Professor; Jacek Wantoch-Rekowski, PhD, dr. habil., Associate Professor: Nicolaus Copernicus University, Faculty of Law and Administration, Władysława Bojarskiego 3, 87-100 Toruń, Poland. 


\section{ABSTRACT}

The amendment to the Act on Road Traffic Law introduced a new legal institution related to failure to register a vehicle consisting of an administrative fine in the amount of PLN 200 to 1,000. The penalty is imposed by means of an administrative decision issued by a competent starost. With the introduction of the above-mentioned institution in legal circulation, new problems will arise in connection with conducting administrative proceedings to impose a penalty, as well as determining its amount. In addition, a starost, as a creditor, is obliged to initiate enforcement proceedings in the absence of voluntary execution of the decision imposing the penalty. The established body aims to ensure the implementation of Directive 2000/53/EC of the European Parliament and of the Council of 18 September 2000 on end-of-life vehicles, concerning, i.a., the absence of sanctions for not registering an imported vehicle and not registering an end-of-life vehicle. The following article discusses the main problems related to the application of the institution introduced with regard to the administrative procedure, the nature of the penalty imposed, as well as its enforcement. The considerations were carried out on the basis of a dogmatic method.

Keywords: registration; vehicle; administrative fine; starost; Road Traffic Law

\section{INTRODUCTION}

As of 1 January 2020, a new legal institution appeared in connection with a failure to perform vehicle registration activities. It is an administrative fine ${ }^{1}$ in the amount of PLN 200 to 1,000, imposed by an administrative decision of a starost, which constitutes an income of the poviat. The indicated institution was introduced as a result of the amendment of the Act on Road Traffic Law ${ }^{2}$ by the Act of 19 July 2019 amending the Act on maintaining cleanliness and order in communes and certain other acts, ${ }^{3}$ which added to the Act on Road Traffic Law, i.a., Articles $140 \mathrm{mb}$ and $140 \mathrm{n}$. It follows from the justification of the draft Act that the purpose of the amendment is to "contribute to improving the compliance of vehicle owners with the obligation to submit an application for registration or deregistration of a vehicle within a specified period of time or the statutory deadline for notification of the purchase or sale of a vehicle, or change in the facts requiring the change of data in the registration certificate. As a consequence, it should also improve the conditions for the legal circulation of vehicles and the ease of reference to the data collected in the central register of vehicles kept by the Minister of Informatisation [...]. The above amendments to the Act - Road Traffic Law are the result of the

1 The concept of administrative penalty and its legal nature are analyzed in many countries. For example, see N. Veloso Giribaldi, El principio de tipicidad en el derecho administrativo sancionatorio, "Revista de Derecho" 2019, vol. 18(36), pp. 69-84.

2 Act of 20 June 1997 - Road Traffic Law (consolidated text Journal of Laws 2020, item 110), hereinafter: RTA.

3 Journal of Laws 2019, item 1579. 
formal allegations of the European Commission concerning the infringement of obligations to transpose Directive 2000/53/EC of the European Parliament and of the Council of 18 September 2000 on end-of-life vehicles, ${ }^{4}$ concerning, i.a., the lack of sanctions for not registering an imported vehicle and not registering an end-of-life vehicle. The Commission found that the Republic of Poland had failed to ensure the effective application of Article 5 para. 2 and Article 6 para. 1 of Directive 2000/53/EC, and thus failed to fulfil its obligations under Article 4 para. 3 of the Treaty on European Union, by failing to provide for penalties applicable to infringements of the obligation to register a vehicle imported into Poland and to inform the competent authority of the acquisition or disposal of the vehicle within the period of 30 days". ${ }^{5}$ The introduced legal and financial instrument "reinforces" the implementation of the registration obligations imposed on vehicle owners. The penalty may affect the entity obliged to register and contribute to the performance of the obligation, as well as cause the performance of obligations which have already fallen due. The secondary effect is an increase in the poviat's income, however, in this respect it is difficult to speak of a specific budgetary effect owing to the fact that it depends on the scale of compliance or lack of compliance with the existing administrative obligations.

The aim of this study is to analyse the problems that may arise during the imposition, collection and enforcement of the administrative penalty imposed.

\section{TEMPORAL ASPECT}

An important issue related to the entry into force of the Act from 1 January 2020 is the issue of the possibility of imposing a penalty in case of failure to comply with the obligation.

There is no doubt that a penalty cannot be imposed on events occurring before 1 January 2020. On the other hand, an issue that may raise doubts is a situation in which the acquisition of the ownership of the vehicle took place before the date of entry into force of the Act, and the obligation was not fulfilled after that date. In this situation, it should be stipulated that the penalty may be imposed only after 30 days from the date of entry into force of the Act. This means that the penalty

4 On Directive 2000/53/EC, see more in S. Mansour, M. Zarei, A multi-period reverse logistics optimisation model for end-of-life vehicles recovery based on EU Directive, "International Journal of Computer Integrated Manufacturing” 2008, vol. 21(7), pp. 764-777; M. Mazzanti, R. Zoboli, Economic instruments and induced innovation: The European policies on end-of-life vehicles, "Ecological Economics" 2006, vol. 58(2), pp. 318-337.

5 Rządowy projekt ustawy o zmianie ustawy o utrzymaniu czystości i porządku w gminach oraz niektórych innych ustaw, Druk nr 3495 z dnia 5 czerwca 2019 r., www.sejm.gov.pl/Sejm8.nsf/ druk.xsp?nr=3495 [access: 10.02.2021]. 
Tomasz Brzezicki, Piotr Rączka, Jacek Wantoch-Rekowski

should be imposed only when the registration of the vehicle has not taken place by 30 January 2020 .

This approach is based on the fact that before 1 January 2020 there was no legal possibility of imposing an administrative penalty for failure to comply with the obligation. The vehicle owner is obliged to register the vehicle within 30 days from the date of acquisition. Therefore, this deadline is to run until the date of entry into force of the provisions enabling the imposition of a penalty. The 30-day deadline for registration provided for in the Act constitutes a sufficient length of time for the vehicle owner to become acquainted with the new legal regulations, which would enable him/her to fulfil this obligation.

Failure to fulfil an obligation is an objective phenomenon. Even if it was not subject to an administrative penalty prior to the date of the amendment, this does not mean that the changes made by introducing an administrative penalty have compensated for the failure to fulfil an obligation. In such a situation no registration under the law has taken place. The infringement is in fact of a continuous nature. It means that failure to register a vehicle within 30 days of its acquisition does not release the owner from the obligation to do so in a situation where the vehicle subject to registration was acquired before the date of entry into force of the provisions on the administrative penalty. Failure to fulfil the obligation within the statutory deadline does not release the owner from the obligation to register the vehicle even if a penalty is imposed.

An interpretation that would impose a penalty only on owners of vehicles acquired after 1 January 2020 would be inappropriate, since the failure to comply with the obligation exists in each of the cases of acquisition of a vehicle in question and it would not be acceptable to differentiate their legal situation with regard to the date of acquisition of a vehicle subject to registration.

In this respect, it is not appropriate to apply the provision of Article 189a of the Code of Administrative Procedure,${ }^{6}$ according to which if, at the time of the decision on an administrative penalty payment, a law other than the law at the time of the infringement which is to result in the imposition of the penalty is in force, the new law is applicable. However, the law previously in force must be applied if it is more favourable to the party. In the event of a continuing infringement, it will not be possible to apply the view according to which the above norm de facto "means imposing a retroactive effect of a law that is more favourable to the infringer of a particular obligation. This rule in principle introduces an obligation to apply the new law. Application of this rule is an obligation of the authority". ${ }^{7}$ The

6 Act of 14 June 1960 - Code of Administrative Procedure (consolidated text Journal of Laws 2020, item 256), hereinafter: CAP.

7 R. Stankiewicz, Regulacja administracyjnych kar pieniężnych w Kodeksie postępowania administracyjnego po nowelizacji, „Radca Prawny. Zeszyty Naukowe” 2017, no. 2, p. 19. 
administrative penalty was introduced only as a result of the amendment mentioned in the introduction, which means that there was no administrative penalty when the registration obligation was fulfilled. This means an obligation to comply with the current rules.

\section{SCOPE OF OBLIGATION}

The administrative penalty is directly linked to the vehicle owner's registration obligations. The legislator directly states in the provision of Article $140 \mathrm{mb}$ RTA that the penalty is to be imposed on the person who:

1) being the owner of a vehicle imported from the territory of a Member State of the European Union, contrary to the provision of Article 71 para. 7, fails to register the vehicle in the territory of the Republic of Poland,

2) being the owner of a vehicle registered in the territory of the Republic of Poland, contrary to the provision of Article 78 para. 2 point 1 , fails to notify a starost about acquisition or disposal of the vehicle.

Prior to the amendment, failure to comply with the registration obligation was penalized under the Code of Petty Offences. ${ }^{8}$ Pursuant to the provision of Article 97 $\mathrm{CPO}$, a road user or any other person on a public road, in the zone of residence or traffic zone, as well as the owner or holder of the vehicle, who violates other provisions of the Act of 20 June 1997 - Road Traffic Law or regulations issued on its basis is subject to a fine of up to PLN 3,000 or a penalty of reprimand.

With the amendment, such penalisation of natural persons has been limited solely to an administrative penalty. This results directly from the provision of Article 140n para. 7 RTA, according to which if a deed which is an infringement referred to in Article $140 \mathrm{mb}$ at the same time exhausts the constituent elements of an offence, then only the provisions on administrative liability apply to the entity being a natural person. Consequently, that means a prohibition to apply in parallel two types of penalties to natural persons. The legislator has not ruled out the possibility of selecting sanctions with regard to legal persons and organizational units.

A public authority should initiate administrative proceedings for the imposition of a financial penalty, whereas the initiation of proceedings in relation to a natural person is obligatory. However, selection of sanctions (administrative or criminal) for entities other than natural persons is not excluded.

The subjective aspect of the administrative penalty imposed also deserves attention. Seemingly, the introduced construct is clear, as it is related to the vehicle

8 Act of 20 May 1971 - Code of Petty Offences (consolidated text Journal of Laws 2021, item 281), hereinafter: CPO. 
owner. Therefore, in the above-mentioned scope, it is necessary to refer to the civil law norms with respect to establishing ownership.

The administrative sanction scheme introduced excludes the possibility of imposing a penalty on autonomous vehicle owners. It would seem that the above statement is strictly theoretical, but it has broad practical connotations in the case of the death of a vehicle owner being a natural person. In such a case, the registration duty will arise only at the moment of the lawful acquisition of the inheritance (court decision or notarial certificate of inheritance).

Another issue that may arise at the stage of the imposition of penalty is related to the situation where the vehicle is jointly owned by several entities. It should be noted in this respect that the penalty is imposed on the owner of the vehicle and is linked to the registration requirement. The obligation to register is a public, non-financial public duty incumbent on each of the vehicle owners and is of an indivisible nature.

The fulfilment of an obligation by one of the co-owners, ${ }^{9}$ leaving aside procedural issues, relieves the others of their obligations. Thus, the performance of the obligation extends to all owners of the vehicle. On the other hand, where an obligation has not been complied with, it is the responsibility of the authority to initiate proceedings to impose an administrative penalty on each of the co-owners separately, regardless of whether the vehicle is subject to fractional or non-fractional co-ownership. Each co-owner is separately liable for failure to fulfil an obligation and this constitutes a personal liability. In this respect, there is no joint and several liability of the co-owners of the vehicle. This means that each of the co-owners can be fined for failure to fulfil the obligation. The amount of the penalty, in this case, may vary and depend on the situation of the co-owner.

\section{FORM OF PENALTY AND COMPETENCE OF THE AUTHORITY}

There is no doubt that the introduced institution is an administrative financial penalty. The legislator, in the provision of Article 140n RTA explicitly indicated that financial penalties, in the cases specified in Articles $140 \mathrm{~m}-140 \mathrm{mb}$, are imposed by way of an administrative decision.

Also, as was necessary, the material competence of the authority to impose a fine was regulated. The competent authority for this purpose is the starost (Article 140 para. 2a RTA). The adopted solution merits approval, as the registration authority is also the authority imposing the penalty.

9 For more on the scope of the registration obligation and its consequences, see R. Stefański, Komentarz do art. 71, [in:] Prawo o ruchu drogowym, LEX/el. 2008. 
The local competence in this respect is regulated by the provisions of the Road Traffic Law in the provision of Article 73. The solutions adopted in this provision are consistent with the solutions adopted in the Code of Administrative Procedure (Article $21 \mathrm{CAP}$ ). The principle is that the registration of a vehicle is made, at the request of the owner, by the starost competent in respect of his or her place of residence (seat), by issuing a registration certificate and legalised registration plates (plate) and a control sticker, if required (Article 73 para. 1 RTA).

A certain problem may arise in the case of non-performance of an obligation in a situation where an object is co-owned by several entities under the jurisdiction of different starosts. In this case, assuming that the penalty is obligatory and indivisible, each starost should conduct a separate administrative procedure for the imposition of the penalty. The appeal body against a starost's decision is the self-governing appeal board.

\section{PROCEDURAL ISSUES}

Proceedings for the imposition of a penalty are administrative proceedings, and the provisions of the Code of Administrative Procedure apply to the ongoing proceedings. Proceedings for the imposition of a penalty are always initiated ex officio, which means that a public administration body is obliged to notify a party to the proceedings (Article $61 \S 4 \mathrm{CAP}$ ). Thus, the date of initiation of proceedings should be taken as the date of the first action taken against a party to the proceedings, i.e. in the case under consideration the date of delivery of the notice of initiation of proceedings for imposing a penalty. ${ }^{10}$

It seems that in view of the detailed regulation contained in the Road Traffic Law concerning the directives for the assessment of penalties, the provisions of the Code of Administrative Procedure, including the provision of Article 189a CAP, do not apply. It should be noted that when determining the amount of a fine, the scope of the infringement, repeatability of infringements, and financial benefits obtained from the infringement of the Act are taken into account (Article 140n para. 4 RTA).

Apart from the "typical" problems of establishing the facts, the principal problem of a starost will be to determine the amount of the penalty. In this respect, the legislator has introduced statutory brackets for its amount. In accordance with the provision of Article 140mb RTA, a penalty of PLN 200 to 1,000 can be imposed. This solution seems to be correct in its premise, as it allows the authority to im-

${ }_{10}$ Similarly B. Adamiak, [in:] B. Adamiak, J. Borkowski, Kodeks postępowania administracyjnego. Komentarz, Warszawa 2011, pp. 291-292; A. Matan, [in:] G. Łaszczyca, C. Martysz, A. Matan, Kodeks postępowania administracyjnego. Komentarz, vol. 1, Kraków 2005, pp. 591-592. 
pose a penalty taking into account factors related to the failure to comply with the registration obligation.

It seems that in the event of failure to comply with the registration obligation, the authority should take into account first of all the issues related to the date on which the registration obligation occurred (or did not occur), which is related to the extent of the infringement. Of course, in the case of natural persons, there may also be issues related to the objective impossibility of fulfilling the obligation, e.g. a chronic illness or, albeit sporadically, a business trip. In this respect, the possibility of penalty mitigation will always be linked to the personal conditions of a party who is a natural person. On the other hand, it appears that the directives on penalty assessment are in the vast majority of cases, related to the repetition of infringements and the financial benefits, which are related to the economic activity of vehicle trading.

Undoubtedly, the penalty "brackets" provided for by law are connected not only with the obligation to carry out certain activities of evidence related to establishing the situation in which a party to proceedings finds itself. Not until the situation of a party is precisely established can a decision be made on the amount of the penalty. From the formal point of view, it is also connected with a correct justification of the issued decision. It should be noted that the provision of Article 107 para. 3 CAP applies in its entirety in this respect. This means that the standard of any decision imposing a penalty should be to refer to the facts of the case. The justification is an "external motivation for an administrative decision". ${ }^{11}$ In this case, it is not only about the circumstances related to the lack of timely registration, which is obvious, but also about the findings influencing the amount of the penalty. This entails the need to conduct investigations in the two areas indicated, which will be subject to both the judicial review and the review by the administrative courts in the event of a complaint against the final decision imposing the penalty in question.

\section{RELIEFS FROM PENALTY}

The legislator decided in favour of a solution, justified from a practical point of view, according to which in the area not regulated by the Act, the provisions of Section III of the Act of 29 August 1997 - Tax Ordinance ${ }^{12}$ - apply accordingly (Article140n para. 6 RTA). It should be stressed that apart from the issues related, e.g., to the possibility of securing the performance of obligations, there is a legal possibility of applying reliefs in relation to the already imposed penalty.

${ }_{11}$ J. Zimmermann, Motywy decyzji administracyjnej i jej uzasadnienie, Warszawa 1981, p. $116 \mathrm{ff}$.

12 Act of 29 August 1997 - Tax Ordinance (consolidated text Journal of Laws 2020, item 1325). 
In accordance with the provision of Article 67a of the Tax Ordinance, at the request of the taxpayer, with reservation of Article 67b, in cases justified by an important interest of the taxpayer or public interest, the tax authority may postpone the date of tax payment or split the payment of the tax into instalments; postpone or split the payment of the tax arrears together with default interest or interest on the tax advances not paid on time; cancel in whole or in part the tax arrears, default interest, or a prolongation fee.

\section{PENALTY AS A POVIAT INCOME}

Pursuant to Article 5 para. 2 point 2 of the Act of 27 August 2009 on Public Finance, ${ }^{13}$ public revenues are other revenues of the state budget, territorial self-government units, and other public finance sector units due under separate acts or international agreements. Z. Ofiarski rightly points out in the literature that "other revenues" may be financial penalties, provided that a separate law clearly specifies their budgetary purpose. ${ }^{14} \mathrm{~A}$ similar view is presented by E. Kornberger-Sokołowska, according to whom "The income to be placed in this category also includes fines and penalties imposed by separate acts. Fines and other penalties constitute payments of a sanctioning nature". ${ }^{15} \mathrm{~A}$ "separate act" is undoubtedly the Road Traffic Law, which in Article 140n para. 3a states that the fines referred to in Articles $140 \mathrm{ma}$ and $140 \mathrm{mb}$ constitute income of the poviat. This is also confirmed by the regulation contained in Article 3 para. 8 of the Tax Ordinance, according to which the term "non-tax budgetary receivables" means receivables other than taxes and fees constituting income of the state budget or budget of a territorial self-government unit resulting from public-law relations. This corresponds with Article 60 of the Act on Public Finance, under which public funds constituting non-tax budgetary receivables of public law character are, i.a., revenues from the budget of a local government unit, e.g. those indicated in this provision. ${ }^{16}$

From the perspective of a poviat, an important regulation is Article 5 para. 1 point 5 of the Act of 13 November 2003 on revenues of territorial self-government units, ${ }^{17}$ according to which the sources of the poviat's own income are revenues from fines and penalties specified in separate regulations. Understandably, the Road

13 Act of 27 August 2009 on Public Finance (consolidated text Journal of Laws 2021, item 305).

${ }^{14}$ Z. Ofiarski, [in:] Ustawa o finansach publicznych. Komentarz, ed. Z. Ofiarski, Warszawa 2019, p. 107.

${ }^{15}$ E. Kornberger-Sokołowska, [in:] Ustawa o finansach publicznych. Ustawa o odpowiedzialności za naruszenie dyscypliny finansów publicznych. Komentarz, ed. W. Misiąg, Warszawa 2019, p. 29.

${ }^{16}$ For more on non-tax government receivables, see P. Majka, [in:] Ustawa o finansach publicznych. Komentarz, ed. Z. Ofiarski, Warszawa 2020, pp. 438-444.

${ }^{17}$ Consolidated text Journal of Laws 2021, item 38. 
Traffic Law introduced an obligation to impose a fine for failure to perform vehicle registration activities on a starost, as he or she is responsible for vehicle registration obligations. As a consequence, the beneficiary of the analysed fine appointed by the legislator is the poviat.

There is no doubt that the fine imposed by the starost for failure to perform registration activities represents the income of the poviat not fulfilling the fiscal function. The poviat's income on this account is a consequence of the vehicle owners' failure to perform their duties, and the fine is designed to perform a punitive function on the one hand and a preventive function (individual and general) on the other. A fine, being an income of the poviat, increases its annual earnings, but certainly has no appreciable financial significance.

\section{ENFORCEMENT OF A FINE AND ENFORCEMENT OF AN OBLIGATION}

As a result of an administrative decision imposing an administrative penalty, the issuing authority imposes a financial obligation on the addressee, the content of which is the payment of the claim referred to in the decision. This obligation will, of course, become effective only when the decision becomes enforceable, which should be assessed in the context of the regulation contained in Article 130 CAP. ${ }^{18}$

The obligation resulting from the decision, of course when it becomes final, or, as is rather doubtful, when it is made immediately enforceable, will belong to the owner of the vehicle who has failed to fulfil his obligation in connection with the regulation contained in Article 71 para. 7 RTA. The addressee of the decision will be obliged to implement the obligation voluntarily, but the observed practice leads to the conclusion that also in the case of this type of penalties, it will often be necessary to resort to legal instruments allowing for the enforcement of the obligation.

The nature of the obligation resulting from a decision imposing an administrative penalty (a public-law obligation) determines that the provisions governing administrative enforcement proceedings will be applicable to its enforcement, i.e. primarily the provisions of the Act of 17 June 1966 on enforcement proceedings in administration. ${ }^{19}$ In particular, owing to the nature of the obligation created as a result of the issuance of a decision on the imposition of a penalty, the performance of which consists in the payment of a defined amount, the provisions of the above-mentioned Act regulating the enforcement of pecuniary claims will apply.

${ }_{18}$ B. Adamiak, J. Borkowski, Postępowanie administracyjne i sq̨dowoadministracyjne, Warszawa 2016, p. 587.

19 Consolidated text Journal of Laws 2020, item 1427, hereinafter: AEPA. More on the subject, see T. Jędrzejewski, M. Masternak, P. Rączka, Administracyjne postępowanie egzekucyjne, Toruń 2020, p. $38 \mathrm{ff}$. 
This determination is of decisive importance for identifying the enforcement authority and the procedure and type of enforcement measures applied. ${ }^{20}$

First of all, the subjective scope of enforcement proceedings should be determined, and in particular who will act as a creditor, debtor, and enforcement authority in these proceedings. Pursuant to Article 1a point 13 AEPA, the creditor in administrative enforcement proceedings is an entity entitled to demand the performance of an obligation or provide its collateral in administrative enforcement proceedings or proceedings to secure claims. However, it follows from the provision of Article 5 para. 1 point 1 AEPA that with respect to obligations arising from administrative decisions (as in the case of the administrative penalty in question), the authority competent to demand the performance of obligations is the body of the first instance.$^{21}$ Thus, in the administrative enforcement proceedings, the creditor in the penalty for not registering the vehicle will be the starost, and in the case where the authority issuing the decision imposing the penalty is the mayor of the city - the creditor will be said mayor (in the case of cities with poviat rights). ${ }^{22}$

The debtor in administrative enforcement proceedings, pursuant to Article 1a point $20 \mathrm{AEPA}$ is, among others, a legal person or an organizational unit without legal personality or a natural person who has failed to satisfy an obligation of a pecuniary nature in a timely manner (the content of the provision not applicable in the cases in question has been omitted). Therefore, the addressee of the administrative decision, i.e. the owner of the vehicle, will act in this capacity, with the exclusion of the complications indicated in the earlier part of the study.

Administrative enforcement proceedings shall be conducted by an enforcement authority. The status of the enforcement authorities in this procedure is provided for in Article 19 AEPA. The analysis of this provision, in the context of the enforcement of an administrative penalty for breach of the obligation to register a vehicle, leads to the conclusion that in this case two situations should be distinguished, namely the first, in which the starost of the poviat district is the creditor of the obligation, and the second, in which the mayor is the creditor of the said obligation. A starost, as stipulated in Article 19 AEPA, may not act as an enforcement authority for financial receivables. Therefore, in a situation where the decision to impose the administrative penalty in question in the first instance will be issued by a starost, then the head of the tax office will be the competent authority to conduct administrative enforcement proceedings (Article $19 \S 1 \mathrm{AEPA}$ ). If the decision to impose

20 T. Jędrzejewski, M. Masternak, P. Rączka, op. cit., p. 171.

${ }^{21}$ More on the subject of creditor, see P. Rączka, T. Jędrzejewski, Wierzyciel w administracyjnym postępowaniu egzekucyjnym, [in:] Administracyjne postępowanie egzekucyjne. Na 50-lecie ustawy o postępowaniu egzekucyjnym w administracji, eds. S. Fundowicz, P. Możyłowski, Radom 2017, p. $54 \mathrm{ff}$.

${ }^{22}$ See Article 92 para. 1 point 2 of the Act of 5 June 1998 on district self-government (consolidated text Journal of Laws 2020, item 920). 
the penalty in question is issued by the mayor of the city in the first instance, it will be necessary to ascertain whether Article 19 para. 2 AEPA is applicable, pursuant to which the enforcement authority in administrative enforcement proceedings will be a municipal authority with the status of a city, listed in separate regulations, and a commune that is part of a Warsaw poviat (Article 19 para. 1 AEPA), in the case of the administrative enforcement of financial receivables for which that authority is competent to assess the amounts and collect penalties. ${ }^{23}$ In this type of cases, therefore, a situation frequently encountered in administrative pecuniary debt enforcement proceedings may occur in which the creditor will simultaneously act as an enforcement authority (with respect to mayors of towns to which Article $19 \S 2$ AEPA applies), or it may be necessary to apply to the head of the tax office, as the competent enforcement authority, for the initiation of proceedings (in other cases). ${ }^{24}$

The enforcement proceedings for a receivable resulting from a decision to impose an administrative penalty for the vehicle owner's failure to comply with the obligation to register it will be governed by the provisions of the Enforcement Act governing enforcement proceedings, and in particular the provisions of Section II of the Act governing enforcement of pecuniary claims. However, the differentiation of enforcement authorities referred to above may result in further complications related to the application of enforcement measures. Pursuant to Article 19 para. 2 AEPA, mayors, as enforcement authorities, are entitled to use all means of enforcing pecuniary claims, except for the seizure of real estate. Therefore, should it be necessary to apply this particularly severe enforcement measure (it seems unlikely given the maximum amount of the penalty in question), a request to apply this measure submitted to the head of the tax office would be required.

${ }^{23}$ In this case, it concerns the municipalities which obtained competence, including with the entry into force of the Act of 24 November 1995 on the amendment of the scope of operation of certain cities and urban public service zones (Journal of Laws 1995, no. 141, item 692). Under this Act, the authorities in question became competent to carry out the enforcement of monetary claims in respect of taxes and fees for which the municipality authority is competent to determine their amounts and collect them. Although the regulation under which large cities acquired competence in this area ceased to apply in connection with the local government reform at the turn of 1998/1999, Articles 87 and 88 of the Act of 13 October 1998 - Provisions introducing Acts reforming public administration (Journal of Laws 1998, no. 133, item 872 as amended) were not applicable. These competences remained the tasks of the cities that had previously participated in the pilot programme. For more on this subject, see T. Jędrzejewski, P. Rączka, Organ gminy jako organ egzekucyjny należności pieniężnych $w$ administracyjnym postępowaniu egzekucyjnym, [in:] 25 lat samorzadu terytorialnego $w$ Polsce. Doświadczenie przeszłości, wnioski na przyszłość, eds. Z. Bukowski, S. Kamosiński, Bydgoszcz 2016, p. $135 \mathrm{ff}$.

${ }^{24}$ T. Jędrzejewski, M. Masternak, P. Rączka, op. cit., p. 79. 


\section{CONCLUSION}

The imposition of an administrative penalty for failure to fulfil an obligation is mandatory. It is not possible for the starost to waive the penalty. In this respect, a "rigid" legal and financial instrument has been introduced in order to ensure fulfilment of the registration obligation. In this respect, the introduced institution should be positively evaluated. On the other hand, the starost has been additionally burdened with administrative obligations in terms of the need to conduct administrative proceedings to impose a penalty. Undoubtedly, at least in the first period of the regulation in force, this will entail organizational challenges for poviat starosts.

Over a certain period of time, an interesting idea would be to carry out quantitative studies on the registration process, as well as on the number and amount of administrative penalties imposed and their significance as income of the poviat, and also to examine how the proposed penalty has affected the implementation of the vehicle registration obligation.

The introduction of the regulation should be considered justified as it strengthens the position of the public administration body in relation to entities which do not perform the statutory vehicle registration obligations. It seems that a certain difficulty, at least in the first period of validity of the institution in question, will be a matter of determining the amount of the penalty to be imposed. In fact, the introduction of a "bracket" as regards its amount may result in a varying practice in terms of setting it by different authorities. However, it seems that in the long run, this problem will be solved by consolidating the practice of the courts.

\section{REFERENCES}

\section{Literature}

Adamiak B., [in:] B. Adamiak, J. Borkowski, Kodeks postępowania administracyjnego. Komentarz, Warszawa 2011.

Adamiak B., Borkowski J., Postępowanie administracyjne i sq̨owoadministracyjne, Warszawa 2016. Jędrzejewski T., Masternak M., Rączka P., Administracyjne postępowanie egzekucyjne, Toruń 2020. Jędrzejewski T., Rączka P., Organ gminy jako organ egzekucyjny należności pieniężnych w administracyjnym postępowaniu egzekucyjnym, [in:] 25 lat samorządu terytorialnego w Polsce. Doświadczenie przeszłości, wnioski na przyszłość, eds. Z. Bukowski, S. Kamosiński, Bydgoszcz 2016.

Kornberger-Sokołowska E., [in:] Ustawa o finansach publicznych. Ustawa o odpowiedzialności za naruszenie dyscypliny finansów publicznych. Komentarz, ed. W. Misiąg, Warszawa 2019.

Majka P., [in:] Ustawa o finansach publicznych. Komentarz, ed. Z. Ofiarski, Warszawa 2020.

Mansour S., Zarei M., A multi-period reverse logistics optimisation model for end-of-life vehicles recovery based on EU Directive, "International Journal of Computer Integrated Manufacturing" 2008, vol. 21(7), DOI: https://doi.org/10.1080/09511920701685325. 
Matan A., [in:] G. Łaszczyca, C. Martysz, A. Matan, Kodeks postepowania administracyjnego. Komentarz, vol. 1, Kraków 2005.

Mazzanti M., Zoboli R., Economic instruments and induced innovation: The European policies on end-of-life vehicles, "Ecological Economics" 2006, vol. 58(2),

DOI: https://doi.org/10.1016/j.ecolecon.2005.06.008.

Ofiarski Z., [in:] Ustawa o finansach publicznych. Komentarz, ed. Z. Ofiarski, Warszawa 2019.

Rączka P., Jędrzejewski T., Wierzyciel $w$ administracyjnym postępowaniu egzekucyjnym, [in:] Administracyjne postępowanie egzekucyjne. Na 50-lecie ustawy o postępowaniu egzekucyjnym w administracji, eds. S. Fundowicz, P. Możyłowski, Radom 2017.

Stankiewicz R., Regulacja administracyjnych kar pieniężnych $w$ Kodeksie postępowania administracyjnego po nowelizacji, „Radca Prawny. Zeszyty Naukowe” 2017, no. 2.

Stefański R., Komentarz do art. 71, [in:] Prawo o ruchu drogowym, LEX/el. 2008.

Veloso Giribaldi N., El principio de tipicidad en el derecho administrativo sancionatorio, "Revista de Derecho" 2019, vol. 18(36).

Zimmermann J., Motywy decyzji administracyjnej i jej uzasadnienie, Warszawa 1981.

\section{Netography}

Rządowy projekt ustawy o zmianie ustawy o utrzymaniu czystości i porządku w gminach oraz niektórych innych ustaw, Druk nr 3495 z dnia 5 czerwca 2019 r., www.sejm.gov.pl/Sejm8.nsf/druk. xsp?nr=3495 [access: 10.02.2021].

\section{Legal acts}

Act of 14 June 1960 - Code of Administrative Procedure (consolidated text Journal of Laws 2020, item 256).

Act of 17 June 1966 on enforcement proceedings in administration (consolidated text Journal of Laws 2020, item 1427).

Act of 20 May 1971 - Code of Petty Offences (consolidated text Journal of Laws 2021, item 281).

Act of 24 November 1995 on the amendment of the scope of operation of certain cities and urban public service zones (Journal of Laws 1995, no. 141, item 692).

Act of 20 June 1997 - Road Traffic Law (consolidated text Journal of Laws 2020, item 110).

Act of 29 August 1997 - Tax Ordinance (consolidated text Journal of Laws 2020, item 1325).

Act of 5 June 1998 on district self-government (consolidated text Journal of Laws 2020, item 920).

Act of 13 October 1998 - Provisions introducing Acts reforming public administration (Journal of Laws 1998, no. 133, item 872 as amended).

Act of 13 November 2003 on revenues of territorial self-government units (consolidated text Journal of Laws 2021, item 38).

Act of 27 August 2009 on Public Finance (consolidated text Journal of Laws 2021, item 305).

Act of 19 July 2019 amending the Act on maintaining cleanliness and order in communes and certain other acts (Journal of Laws 2019, item 1579).

\section{ABSTRAKT}

Nowelizacja ustawy Prawo o ruchu drogowym wprowadziła nową instytucję prawną związaną z brakiem dokonania zarejestrowania pojazdu, jaką jest administracyjna kara pieniężna w wysokości od 200 do 1000 zł. Kara nakładana jest w drodze decyzji administracyjnej przez właściwego starostę. 
Wraz z wejściem do obrotu prawnego powyższej instytucji pojawią się nowe problemy związane z prowadzeniem postępowania administracyjnego w przedmiocie nałożenia kary, a także ustalenia jej wysokości. Ponadto starosta jako wierzyciel jest zobowiązany do wszczęcia postępowania egzekucyjnego w sytuacji braku dobrowolnego wykonania decyzji nakładającej karę. Wprowadzona instytucja ma na celu zapewnienie realizacji dyrektywy Parlamentu Europejskiego i Rady 2000/53/ WE z dnia 18 września 2000 r. w sprawie pojazdów wycofanych z eksploatacji, dotyczącej m.in. braku sankcji za niezarejestrowanie importowanego pojazdu oraz niewyrejestrowanie pojazdu wycofanego z eksploatacji. W niniejszym artykule omówiono główne problemy związane ze stosowaniem wprowadzonej instytucji w zakresie procedury administracyjnej, charakterem nakładanej kary oraz jej egzekucji. Rozważania przeprowadzono w oparciu o metodę dogmatyczną.

Słowa kluczowe: rejestracja; pojazd; administracyjna kara pieniężna; starosta; Prawo o ruchu drogowym 